\title{
VÝVOJ PODZEMNÍHO ODTOKU VE VÝCHODNÍ POLOVINĚ ČR
}

\author{
Baseflow evolution from the eastern part of the Czech Republic \\ Petr Vaníček $\square$, Kateřina Chroustová, Josefína Bízová, Adam Říčka \\ Ústav geologických věd, PřF MU, Kotlářská 2, 61137 Brno
}

Key words: eastern part of the CR, climate changes, groundwater storage, baseflow, groundwater depletion

\begin{abstract}
The depletion of groundwater storage caused by the climate changes is frequently discussed issue. Thus, the baseflow evolution from 2006 to 2015 (at two locations from 1994 to 2016) was assessed at 10 watersheds situated in the eastern part of Czech Republic. Six observed watersheds are situated in the crystalline rocks (Strážek Moldanubicum and Orlice-Sněžník Unit) and four in sedimentary rocks (Vienna Basin, Ždánice Unit, Vysoké Mýto Syncline and Ústí Syncline). The evolution of the groundwater storage and baseflow is based on the springs and rivers flow rates evaluation respectively. The groundwater storage evolution from the spring watersheds was determined by the Maillet equation. The automated baseflow separation accomplished by PART (USGS) program was applied for the river watersheds and then expressed by linear regression in MS Excel. The long-term decrease of groundwater storage and baseflow was revealed in all observed watersheds. The rate of this decline is very different in each watershed and ranges from 10 to $85 \%$. The increase of groundwater exploitation or change of vegetation cover or seasonal distribution of groundwater recharge was not confirmed. Relating to the correlation between precipitation and baseflow evolution, the reason for groundwater depletion resides in the decreasing amount of precipitation.
\end{abstract}

\section{Úvod}

K často diskutovaným tématům poslední doby patří změny klimatu a jejich dopad na veškeré př́rodní procesy. V př́rodních podmínkách České republiky je jejich prŕíčinou nedostatek srážek, který způsobuje pokles hladiny nejen povrchových, ale i podzemních vod, které mají pro společnost zásadní význam a často se využívají jako zdroj pitné i užitkové vody. Pokles zásob podzemních

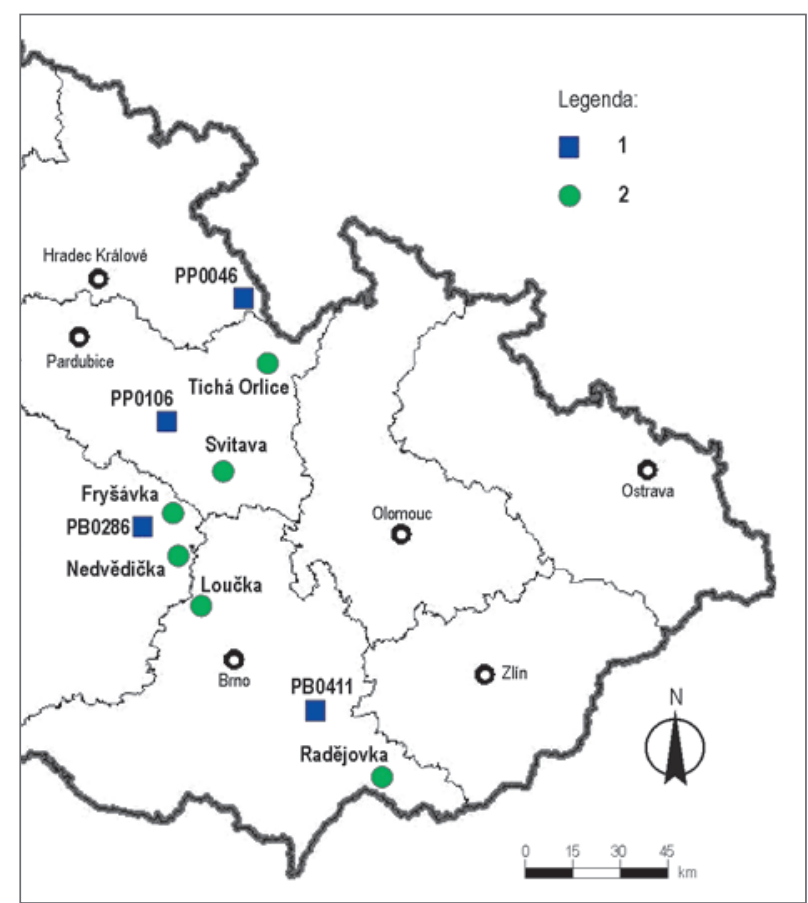

Obr. 1: Lokalizace hodnocených pramenů (1) a měrných profilů (2) na vodních tocích.

Fig. 1: Location of studied springs (1) and measured stream profiles (2).

$\Xi$ 437281@mail.muni.cz

DOI: https://doi.org/10.5817/GVMS2018-1-2-124 vod dokládá například pokles hladin ve vodních nádržích, snižující se průtoky ve vodních tocích nebo klesající vydatnosti u pramenů. Pokles podzemního odtoku v krystaliniku ČR dokládá např. Hrkal et al. (2009) dlouhodobým snižováním hladiny podzemních vod.

Pro posouzení stavu zásob podzemní vody ve v. polovině ČR byl na 10 lokalitách zhodnocen vývoj podzemního odtoku (obr. 1), který lze v podmínkách mírného klimatického pásu a za neovlivněných nebo pouze málo ovlivněných přírodních poměrů ztotožnit $s$ množstvím vody, která infiltrovala do př́slušného zvodněného systému (Krásný et al. 2012). Efektivní infiltrace (EI) je tedy shodná s odtokem podzemní vody do povrchových toků, jestliže nedochází $\mathrm{k}$ dalším př́růstkům nebo ztrátám vody do nebo ze systému (Rutledge 2000). Přírodní zásoby podzemní vody jsou tedy reprezentovány podzemním odtokem (Krásný et al. 2012).

\section{Př́írodní poměry a lokalizace}

Nejsevernější hodnocenou lokalitou je povodí Tiché Orlice, která se, stejně jako pramen PP0046 (Rokytnice v Orlických horách, Hanička 3), nachází v oblasti orlicko-sněžnického krystalinika tvořeného ortorulami, rulami a migmatity. Keka Svitava leží společně s pramenem PP0106 (Zderaz, Kapalice) ve východní části české kř́ídové pánve s dominantní převahou pískovců, jílovců a slínovců. V oblasti strážeckého moldanubika byla hodnocena povodí vodních toků Fryšávky, Loučky, Nedvědičky a pramen PB0286 (Nové Město na Moravě, Ski I), kde převládají ruly, případně ortoruly a migmatity. Poslední, a zároveň nejjižněji hodnocenou lokalitou bylo povodí řeky Radějovky ve vídeňské pánvi a pramene PB0411 (Lovčice u Kyjova, Jordánek), který se nachází ve ždánické jednotce vnější skupiny př́krovů Západních Karpat, reprezentovaného výskytem pískovců a slínovců. 


\section{Metodika}

Podzemní odtok byl zhodnocen z povodí řek Svitavy (Hradec nad Svitavou), Tiché Orlice (Sobkovice), Radějovky (Petrov), Fryšávky (Kadov), Loučky (Skryje) a Nedvědičky (Rožná) a povodí pramenů PP0106 (Zderaz, Kapalice), PP0046 (Rokytnice v Orlických horách, Hanička 3), PB0411 (Lovčice u Kyjova, Jordánek) a PB0286 (Nové město na Moravě, Ski I) - viz obrázek 1. Data průměrných denních průtokůa týdenních vydatností pramenů byla poskytnuta Českým hydrometeorologickým ústavem (ČHMÚ) a následně zpracována v programu PART a Mailletovou rovnicí.

\section{Mailletova metoda}

Mailletova rovnice (Maillet 1905) vychází z Boussinesquovy rovnice (Boussinesq 1904), pomocí které lze taktéž popsat klesající rameno v hydrogramu a určit doplňování podzemních vod.

$Q_{t}=Q_{0} \times e^{\alpha\left(t-t_{0}\right)}$

kde $Q_{0}$ je vydatnost pramene na začátku recese, $Q_{t}$ je vydatnost $v$ čase $t$, e je základ přirozeného logaritmu $a$ je recesní koeficient. Ten muže být spočten $\mathrm{z}$ rovnice 2 (Korkmaz 1990):

$\alpha=\frac{l_{n} Q_{\max }-l_{n} Q_{\min }}{t}$

Po výpočtu recesního koeficientu se rovnicí 3 vypočítá objem vody $V\left(\mathrm{~m}^{3}\right)$ ve zvodni:

$V=\frac{86400 \times Q}{\alpha}$

kde 86400 je počet sekund za den a $Q$ je vyprazdňování $\left(\mathrm{m}^{3} / \mathrm{s}\right)$.

\section{Part}

Jako vstupní data do programu Part byly využity denní průtoky ze stanic ČHMÚ. Program pracuje na základě metody separace hydrogramu. Využívá možnosti rozčlenění průtoku řeky na povrchový odtok a odtok podzemní. Skenuje záznamy dní, které se shodují s požadavky předcházející recese. Určí bazální průtok, který se rovná celkovému

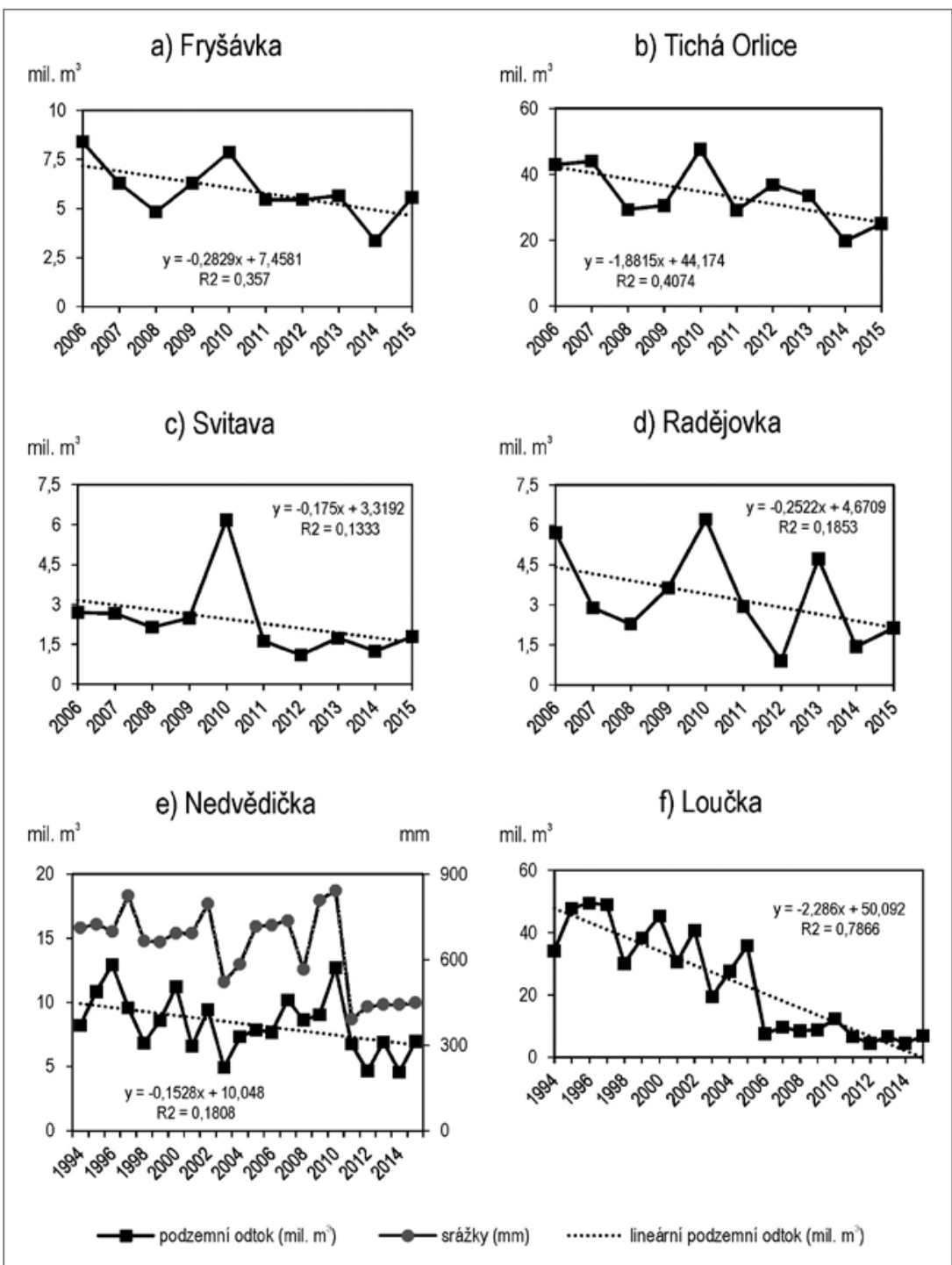

Obr. 2: Vývoj ročního podzemního odtoku u sledovaných povodí toků. Fig. 2: Evolution of annual baseflow from studied river watersheds. průtoku v těchto dnech, poté lineárně interpoluje denní záznam podzemního průtoku pro dny, které neodpovídají požadavku předcházející recese. Program je aplikován na dlouhou dobu záznamu, čímž se získá odhad o průměrné rychlosti odtoku podzemní vody (Rutledge 1998).

V podstatě program považuje průtok v toku za podzemní odtok po určité době od srážkového eventu dle rovnice 4 (Linsley et al. 1982):

$N=A^{0,2}$

kde $N$ je počet dní od srážkového eventu a $A$ je plocha povodí ve čtverečních mílích.

\section{Výsledky}

Ve sledovaných povodích řek Svitavy $\left(55,20 \mathrm{~km}^{2}\right)$, Tiché Orlice $\left(98,45 \mathrm{~km}^{2}\right)$, Radějovky $\left(41,02 \mathrm{~km}^{2}\right)$ a Fryšávky $\left(20,93 \mathrm{~km}^{2}\right)$ byl určen podzemní odtok, resp. EI za období let 2006-2015, u povodí řek Loučky $\left(222,2 \mathrm{~km}^{2}\right)$ a Nedvědičky $\left(56,8 \mathrm{~km}^{2}\right)$ za období let 1994-2015.

Hodnoty podzemního odtoku jsou u povodí řek Svitavy (obr. 2c) a Radějovky (obr. 2d) srovnatelné a pohybují se průměrně od 950 tis. $\mathrm{m}^{3} /$ rok do $6,2 \mathrm{mil}$. $\mathrm{m}^{3} /$ rok. V povodí Tiché Orlice 
(obr. 2b) byl podzemní odtok výrazně vyšší a jeho hodnoty se pohybují od $19,7 \mathrm{mil} . \mathrm{m}^{3} /$ rok do 47,6 mil. $\mathrm{m}^{3} /$ rok. U nejmenšího sledovaného povodí Fryšávky (obr. 2a) se hodnoty podzemního odtoku pohybovaly od $3,4 \mathrm{mil} . \mathrm{m}^{3} /$ rok do 8,4 mil. $\mathrm{m}^{3} /$ rok. Hodnoty podzemního odtoku se u povodí Loučky (obr. 2f) pohybovaly od 4,5 mil. $\mathrm{m}^{3} /$ rok do 49,5 mil. $\mathrm{m}^{3} /$ rok a u Nedvědičky (obr. 2e) od 4,5 mil. $\mathrm{m}^{3} / \mathrm{rok}$ do $12,9 \mathrm{mil} . \mathrm{m}^{3} / \mathrm{rok}$.

U všech povodí byl zaznamenán shodný vývoj trendu podzemních odtoků (obr. 2), který má klesající charakter. Z vývoje srážkových úhrnů v povodí řeky Nedvědičky (obr. 2e) je zř̀mé, že během sledovaného období dochází také $\mathrm{k}$ poklesu srážkových úhrnů (stanice ČHMÚ Sejř̀ek).

Podzemní odtok v povodích zájmových pramenů PP0106, PP0046, PB0411 $\left(0,413 \mathrm{~km}^{2}\right)$ a PB0286 byl hodnocen $\mathrm{v}$ rámci hydrologických let 2007-2015 (obr. 3). $\mathrm{Z}$ důvodu nevýrazné morfologie terénu nebylo možné jednoznačně určit plochu povodí u ostatních pramenů.

U tří ze sledovaných pramenů PP0106, PP0046 a PB0286 (obr. 3a, b, c) byly zaznamenány shodné trendy podzemního odtoku, které měly klesající charakter. Ze všech hodnocených povodí je jedinou výjimkou povodí pramene PB0411 (obr. 3d), ve kterém byl identifikován vzestupný charakter doplňování zásob podzemních vod.

\section{Diskuze}

Ve všech hodnocených povodích, s výjimkou povodí pramene PB0411, byl indikován pokles podzemního odtoku. Ten může být způsoben několika faktory. Jedním z nich je evaporace, která se vlivem globálního oteplování zvyšuje. Dalším významným faktorem je vývoj jímání podzemních vod ve studovaných povodích. Podle databáze Výzkumného ústavu vodohospodářského T.G. Masaryka (heis.vuv.cz) však v průběhu studovaného období nedocházelo ke zvyšování jímání podzemních vod nebo k výrazným změnám skladby vegetačního pokryvu u většiny sledovaných lokalit, s výjimkou povodí Nedvědičky a Loučky, u kterých nebylo k dispozici dostatečné množství potřebných podkladů (www.mapy.cz). Pokles podzemního odtoku tedy není způsoben těmito faktory. Hlavní prríčina poklesu podzemního odtoku patrně spočívá ve změně vývoje deštových srážek. Srovnáním výsledných hodnot doplňování podzemních vod v průběhu všech hodnocených roků a jednotlivých ročních období bylo zjištěno, že na žádné z hodnocených lokalit nedochází ke změně vývoje doplňování podzemních vod v průběhu roku. Hlavní období doplňování podzemních vod i nadále náleží jarní sezóně, zatímco období nejnižšího doplňování podzemních vod náleží podzimnímu období, jak je ukázáno např. na vývoji rozložení podzemního odtoku v povodí Tiché Orlice (obr. 4). Podstatná příčina poklesu doplňování podzemních vod tedy tkví v poklesu ročních srážkových úhrnů, což dokládá například vývoj ročních srážkových úhrnů ze srážkoměrné stanice Sejřek (ČHMÚ), nacházející se v oblasti povodí vodních toků Loučka a Nedvědička (obr. 2e, f).

Rozdílná velikost poklesu podzemního odtoku z jednotlivých povodí je způsobena odlišnou geologickou stavbou, morfologií terénu, nadmořskou výškou jednotlivých povodí, odlišným charakterem vegetačního pokryvu a odlišnou intenzitou srážek.

\section{Závěr}

Vývoj podzemního odtoku z 10 vybraných povodí byl sledován po dobu desíti až dvaceti let. Bylo zjištěno, že k nárůstu podzemního odtoku dochází pouze u pramene PB0411. U ostatních lokalit dochází k poklesu podzemního odtoku. Míra tohoto poklesu v letech 2006 až 2015 vyjádřená lineární regresí dosahuje přibližně u povodí řeky Svitavy $50 \%$, u povodí Tiché Orlice $60 \%$, u povodí Radějovky $10 \%$, u povodí Fryšávky $31 \%$, u povodí pramene

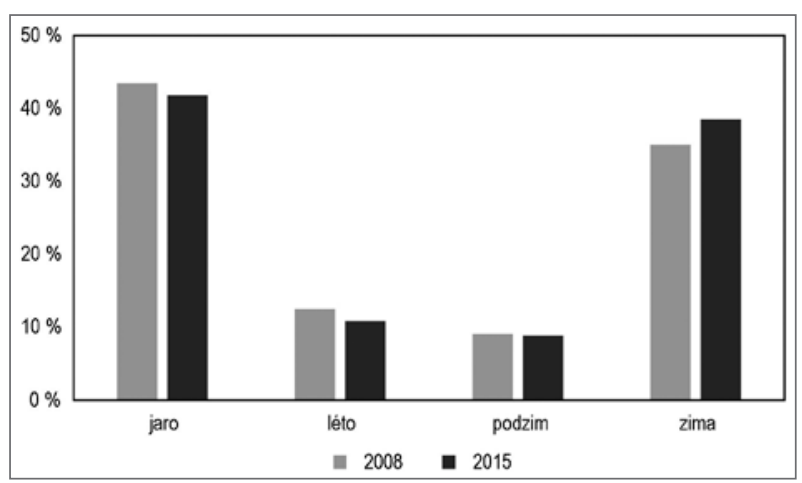

Obr. 4: Sezónní rozložení podzemního odtoku z povodí Tiché Orlice v roce 2008 a 2015.

Fig. 4: Seasonal distribution of baseflow from Tichá Orlice watershed in 2008 and 2015. 
PP0106 25\%, u povodí pramene PP0046 $70 \%$ a u povodí pramene PB0286 5\%. Kvantifikace změny podzemního odtoku je u některých lokalit ovlivněna extrémními hodnotami ročního podzemního odtoku. Př́íkladem je popsaný poklesový trend u pramenů PB0106 a PB0046 zvýrazněný extrémně vysokým doplněním podzemních vod v roce 2010 (PB0106) a 2008 (PB0046). Povodí pramene PB041 je jedinou lokalitou, kde došlo ke zvýšení doplňování zásob podzemních vod cca o $42 \%$. V letech 1994 až 2015 došlo v povodích řek Loučky a Nedvědičky, podle trendu vývoje podzemního odtoku, k poklesu přibližně až o $85 \%$ a $35 \%$.
Zhodnocením faktorů, které by mohly mít na vývoj podzemního odtoku vliv, bylo zjištěno, že př́ičina převládajícího poklesu v doplňování zásob podzemních vod spočívá především v klesajícím vývoji ročních srážkových úhrnů.

\section{Poděkování}

$\mathrm{Na}$ tomto místě bychom rádi poděkovali editorưm a recenzentům za cenné komentář́, které vedly ke zkvalitnění př́spěvku. Dále bychom chtěli poděkovat pracovníkưm Českého hydrometeorologického ústavu za poskytnutí hydrogeologických dat.

\section{Literatura}

Boussinesq, J. (1904). Recherches the'oriques sur l'e'coulement des nappes d'eau infiltre'es dans le sol et sur le de'bit des sources. - Journal de Mathématiques Pures et Appliquées., 10, 5-78.

Hrkal, Z., Milický, M., Tesař, M. (2009). Climate change in Central Europe and the sensitivity of the hard rock aquifer in the Bohemian Massif to decline of recharge: case study from the Bohemian Massif. - Springer-Verlag. 703-713.

Korkmaz, N. (1990). The estimation of groundwater recharge from spring Hydrographs. - Hydrological Sciences Journal, 37, 247-261.

Krásný, J., Císlerová, M., Čurda, S., Datel, J. V., Dvořák, J., Grmela, A., Hrkal, Z., Kř́žz, H., Marszalek, H., Šantrůček, J., Šilar, J. (2012). Podzemní vody České republiky: Regionální hydrogeologie prostých a minerálních vod. - Česká geologická služba, Praha.

Linsley, R. K., Jr Kohler, M. A., Paulhus, J. L. H. (1982). Hydrology for engineers, 3rd ed. - New York: McGraw-Hill. 691 pp.

Maillet, E. (1905). Essais d'hydraulique souterraine et fluviale. Librairie Sci. - Paris: A. Hermann. 218 pp.

Rutledge, A. T. (1998). Computer programs for describing the recession of ground-water discharge and for estimating mean groundwater recharge and discharge from streamflow records-update. USGS. - Water-Resources Investigations Report 98-4148. $42 \mathrm{pp}$.

Rutledge, A. T. (2000). Considerations for use of the RORA program to estimate ground water recharge from streamflow records. - USGS. Open-file Report 00-156. 43 pp.

www stránky: heis.vuv.cz 2017: Mapa: vodní hospodářství a ochrana vod (podklad mapy ČÚZK) s odběry podzemních vod 2006-2015. - Dostupné na: https://heis.vuv.cz/, 16. 04. 2017.

mapy.cz: Letecká mapa. - Dostupné na: https://mapy.cz/letecka?x=15.6377065\&y=49.6107355\&z=7, 14. 04. 2017. 